\title{
THE ASSESSMENT OF THE COMMON AGRICULTURAL POLICY REFORM AFTER 2013 FROM - POINT OF VIEW OF POLISH AGRICULTURE
}

\author{
Bazyli Czyżewski ${ }^{1}$ \\ Sebastian Stępieńn ${ }^{2}$
}

\begin{abstract}
The evolution of the Common Agricultural Policy is marked by distinct graduality. The first stage was subject to food self-sufficiency priority, the second was clearly of a pro-demand character. The third stage, related to the Common Agricultural Policy (CAP) reform after 2013, is distinguished by changes in the model of the agricultural sector products consumption, and takes into account usefulnesses connected with the well-being of the natural environment and provision of public goods. The aim of this article is to point out proposals of changes in the EU agricultural policy, especially in the scope of the direct subsidies mechanism, from the point of view of the benefits for rural areas in Poland. The authors indicate that the utmost pro-efficiency and modernization orientation of the $1^{\text {st }}$ and $2^{\text {nd }}$ pillar of CAP within current institutional frameworks is in the interest of the Polish agriculture.
\end{abstract}

Key words: agriculture, UE, policy, reform, results

JEL Codes: E02, Q18

Introduction

Since its creation in the 1950's, the Common Agricultural Policy (CAP) has gone through significant changes, from a policy geared towards increasing supply and ensuring food selfsufficiency through supporting agricultural incomes and stimulating internal demand, to directing it towards sustainable growth equally considering economic, social and environmental criteria. The next period of EU 2014-2000 budget programming and further CAP reforms are now ahead of us. They will take place under conditions of adjustments to the new limitations resulting from the agricultural negotiations within WTO, challenges related to changes in the natural environment, and a will to limit the EU budgetary funds allotted to the rural areas and agriculture under the pressure of some member states and tax payers' criticism. The next financial perspective will then be planned under the influence of internal and external factors different from the past ones. Therefore, there is a need of a comprehensive assessment paying special attention to economic effectiveness, social adequacy, and health and ecological criteria. CAP will evolve towards harder and harder policy, and obtaining funds will involve meeting new criteria for realizing new goals.

The new mechanisms of the EU agriculture policy need to take into account deepening of the globalization processes, running through, inter alia, the concentration of productive factors and mounting inequalities in the division and depreciation of agriculture. Globalization causes the market to push with redoubled strength towards microeconomic effectiveness (today - corporate). And relying on the effectiveness relations, it does neither solve the food problem nor the income problem. However, it gives rise to new challenges, because the external effects, especially environmental ones, are being transferred to the global level (Zegar, 2010a). Therefore, there exists a need of adjusting to the globalization processes, while simultaneously creating coordinating instruments at the supranational level. The lack of any coordination of this policy in the EU

\footnotetext{
${ }^{1}$ Poznań University of Economics, Poland, e-mail: bazylicz@interia.pl.

${ }^{2}$ Poznań University of Economics, Poland, e-mail: sebastian.stepien@ue.poznan.pl.
} 
together with a reduction of national support may lead to a scenario according to which countries would compete solely through global prices and microeconomic effectiveness, assuming global standardization of quality and consumption. Therefore food would be produced in the cheapest locations with the cheapest labour force.

The aim of the hereby article is to present proposals of changes in the common agricultural policy after 2013 in the context of rural areas development in Poland. It places special emphasis on the issues related to the mechanism of the direct subsidies which occupy most of the public debate and whose form arouses many controversies. The authors attempt to present their own opinions on the adopted agreements on the basis of the European Commission documents and the standpoints of scientific institutions and experts. Since the intention of the hereby publication is to, inter alia, point out the proposals of changes in the support mechanism, it is partially a review in nature. Such an approach enables deeper understanding of the EU agricultural policy and allows us to assess the future reforms. The emphasis has been put on the application aspect and an explanation of the proposed changes, and what they might indicate in terms of agriculture, especially in terms of rural areas in Poland. The arguments will be preceded by a discussion on the effects of the agricultural policy in 2007-2013.

\section{Methods}

This analysis is based on 2007-2013 data from the Farm Accounts Data Network (FADN) in Poland and a survey conducted by authors concerning institutional (qualitative) and quantitative factors of individual farms' incomes using 400 representative farms from all FADN regions of Poland (Czyżewski 2013, chapter 6). The sample of individual farms in the main types of farming ${ }^{3}$ have been divided into two classes:

1) those which accumulate residual income equal (or higher) to the amount of land rent derived from local land prices; that class has been named "developing farms";

2) those which don't accumulate residual income in above mentioned level; that class has been named "non-developing farms".

Authors used logit regression to identify a set of statistically significant variables both qualitative and quantitative which determine belonging to the mentioned classes. Then the parameters of logit regression models of a different types of farmimg have been estimated. In that way authors have recognized the farming types in Poland which develop mainly through the "institutional rents" and "differential rents" according to the ricardian terminology (Czyżewski 2010). Generally it can be said that at present fieldcrops and grainvores (pigs) types in Poland could acquire "institutional rents" in opposite to horticulture, other permanent crops and milk types which get "differential rents". Next authors estimated a proportion of agricultural land in hectares in Poland attributed to those two subpopulations described by "institutional" or "differential" development path. An assumption has been made that the division of CAP funds after 2013 in Poland into pro-equality and pro-efficiency measures should keep the similar proportion because pro-efficiency measures are to stimulate "differential rents" and pro-equality funds - "institutional rents". The next question for which authors seek an answer in table 1 is if such allocation of CAP funds will be possible after 2013 in Poland.

\section{Evaluation of the support policy for rural areas in 2007-2013 - a review of the source materials}

The opinions on the absorption of resources from the Rural Development Program (RDP) for the years 2007-2013 and possibilities to achieve the above macroeconomic goals are ambiguous.

\footnotetext{
${ }^{3}$ Fieldcrops, horticulture and other permanent crops, milk, grainvores (pigs)
} 
In the scope of the medium-term evaluation of the program realization (for the years 2007-2010), some expert opinions indicate a high probability that the macroeconomic guidelines of the program will be realized (Ocena Średniookresowa..., 2010). For example, it has been found that "in case of most of the actions, reaching the product and result indicator at the end of the programming period

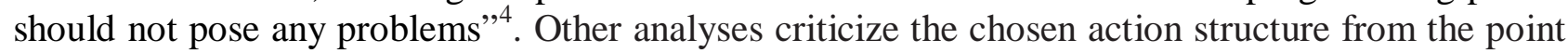
of view of the assumptions made and the organization of the subsidies distribution system within RDP 2007-2013 (Rowiński, 2008). Below, the article presents the effects of RDP (both positive and negative) that determined the mechanism of allocating economic rents to farming and generally influenced the rural areas development in Poland.

Undoubtedly, Poland, with its agriculture and rural areas, became a net beneficiary of the EU budget (in the first five years of its membership the ratio of receipts within CAP to Poland's contribution to the EU budget was over 1.5). Participation of the Polish institutions and farms in CAP and other community policies contributed to the increasing level of support for farming (Czyżewski, 2010). Since Poland joined the EU, budget expenditures have increased mainly thanks to co-financing the EU programs and financing direct payments. In comparison with the period prior Poland's accession to the EU, there has also been a significant increase in the share of spendings on the agricultural sector in the total budget expenditures. In 2009 the ratio was 2.7 times higher than this year ${ }^{5}$. The increase of the real value of the agricultural production and the margin squeeze in favour of agriculture ${ }^{6}$ resulted in a considerable increase of the Polish agricultural income level and a reduction of disparity between agricultural incomes and the average remuneration in the national economy. For the first five years of Poland's membership the real income of agricultural producers increased by over $110 \%$, mainly thanks to the direct subsidies that have been used by $80 \%$ of farmers.

However, several issues may be raised against this background. First, it concerns the question of work efficiency in agriculture. Despite the fact that, according to the estimates of the report (Ocena Średniookresowa..., 2010) presented by the Ministry of Agriculture and Rural Development, thanks to RDP 2007-2013, in the years 2007-2009 the GDP level increased by $0.22 \%$ and the number of the employed increased by $0.28 \%$, the effects in the scope of the total increase of work efficiency in agriculture are almost nonexistent (in comparison with the forecast changes) ${ }^{7}$, whereas the Program's significant influence on this indicator has been assumed. What is interesting, though, is that the overall increase in the number of jobs in Poland significantly exceeded the expectations for the period 2007-2015, and the share of RDP in the increase was explicit according to the estimations, thanks to RDP 2007-2013 the employment in Poland will increase by approximately 250,000 people by the year 2015 .

However, other macroeconomic models do not confirm the nation-wide trend and indicate a weak but permanent influence of RDP on work efficiency (calculated as GDP per working person) in Poland. In the years 2007-2013 work efficiency is forecast to increase by $0.344 \%$ on average, which leads to a conclusion that RDP has a relatively stronger influence on the added value than the

\footnotetext{
${ }^{4}$ A target level of adopted indicators raised doubts, for example in programs: "Use of advisory services by farmers and forest holders" and "Participation of farmers in food quality schemes".

5 A.Czyżewski, Co dała integracja europejska polskiej wsi - w opinii ekonomisty, [w:] Polska wieś 2010. Raport o stanie wsi, J.Wilkin, I.Nurzyńska (red.), Fundacja na rzecz Rozwoju Polskiego Rolnictwa, Warszawa 2010, s. 164-166.

${ }^{6}$ In the period 2004-2009 the real value of agricultural production increased in comparison with the period 1999-2003 more than $17 \%$, with an increase of the intermediate consumption by $13.5 \%$. The index "price scissors" (the ratio of prices received by farmers to prices of products purchased) in 2004-2008 was 98.5, with a value of 88.6 in the period 2000-2003. See: (Poczta, 2010).

${ }^{7}$ At the end of 2009, 53.7\% of the target RDP impact on economic growth was achieved, $49.1 \%$ of the target impact on job creation and $0 \%$ in productivity. Thus, the target level of RDP's impact on the mentioned two indicators have already been completed in the period 2007-2009 almost in half. That conclusion doesn't concern the labor efficiency. See: (Ocena Średniookresowa..., 2010).
} 
labour market (Zaleski et al., 2007). With reference to the agriculture itself, the data published by the Central Statistical Office confirms this conclusion (Rocznik Statystyczny..., 2011). Employment in agriculture calculated in $\mathrm{AWU}^{8}$ is virtually constant in 1997-2009 (approx 2300 thousand AWU and growing insignificantly), and the added value of the section (at fixed prices, the previous year $=100$ ) is systematically growing by approx 5\% annually (in the years 1997-2009). Summing up, the share of RDP 2007-2013 in the increase of work efficiency is not explicit. However, it has been known that if it influenced this indicator, it was not through substituting own work and decreasing its involvement in agriculture, but through the increase of the added value of agricultural production.

The next significant aspect concerns the expected multiplier effects of RDP 2007-2013 and their implications for the next programming period. The authors of the cited above report claim that: "the results of the macroeconomic model simulation confirm that most of benefits of the RDP 2007-2013 are indirect. In the year 2015, the total agricultural sector production will be $0.6 \%$ higher than it would be in the same period if the Program was not being realized. Simultaneously, owing to the program realization, in the same period the whole economy's production level will be higher by approx $0.8 \%$. (...) In accordance with the macroeconomic model forecasts, as a result of RDP 2007-2013 the aggregated growth of the total GDP of Poland in the years 2007-2015 will amount to less than 80 billion PLN (value in prices from the year 2000), and by 2020 it will increase by approx. 110 billion PLN (...)". The evaluation of the above facts is ambiguous. The consumption demand is rather stimulated by the social nature of support. And the investment demand is stimulated by the modernization subsidies. In the first case, however, the biggest benefits are reached by the $3^{\text {rd }}$ food economy zone, i.e. the food-processing industry, which strengthens asymmetry of rents division in this zone's favour (as a result of the economic surplus outflow from agriculture to food processing $)^{9}$. In the second case, apart from the agriculture itself also the $1^{\text {st }}$ food economy zone (suppliers of resources and services for production) benefits from the multiplier effects but it does not take over to such an extent as the $3^{\text {rd }}$ land rent zone. And thus the modernization and organizational processes increase agricultural effectiveness and improve rent allocation in favour of the agricultural sector (Rowiński, 2008). Therefore, in the programming period 2014-2020, some pressure should be put on the competitiveness and productivity of the Polish agriculture. This case is all the more alarming and difficult because the proposals of the European Commission are heading in the direction of increasing the role of so-called decoupling (the removal of the link between the direct payments and the size of production) and of proenvironmental funds (reference below).

The evaluation of the sustainable development concept realization is another problem. Does equal allocation of public resources to actions supporting rural areas development, environmental protection and agricultural incomes really means effective realization of the three goals? The experts claim that the medium-term evaluation (at the end of 2009) showed that the Program effectively realizes the above concept in all three aspects: economic, social and environmental. However, an analysis of the land rent allocation in the long-term challenges the thesis. According to the adopted assumptions, the asymmetry in the division of rents may first result in disturbances in the social aspect (in the context of fair remuneration of the work unit), which is a necessary condition for sustainability. Next, the economic profitability (i.e. the realization of a full-value land rent - so-called sufficient condition) is at risk, leading, as a result, to the lack of funds for land resources rehabilitation, indispensable to achieve the environmental goals. Therefore, a conclusion arises that an equal division of funds between the individual prerogatives of the sustainable

\footnotetext{
${ }^{8}$ AWU - Annual Work Unit, corresponds to the work performed by one person who is occupied on an agricultural holding on a full-time basis.

${ }^{9}$ Due to the fact that the social support does not enhance real agricultural productivity, does not increase the bargaining power of agriculture, or does not conducive to the creation of institutional structures, mitigating drainage of rent.
} 
development cannot guarantee it. On the contrary, a certain disproportion in the share is desirable; a disproportion that is oriented to increasing the added value of the agricultural production while meeting specific requirements of interdependence of the economic and environmental goals (crosscompliance). The above approach is based on a specified goal hierarchy: first comes social balance (with respect to the parity remuneration of a work unit), then economic, and environmental at the end. It is an alternative for a multi-criteria concept of a common agricultural policy, assuming simultaneous realization of all the three premises of sustainable development. As for the Poland's reason of state, according to the authors, there are objective premises to submit the form of the next programming period to the gradation proposed above (reference below).

\section{Proposed CAP reforms from the point of view of the Polish rural areas' interests}

New challenges that agriculture will have to face imply the necessity of reorienting the intervention mechanisms. The most important question today does not concern the size of the union budget (there is a sort of a common agreement of the member states, in this matter, to maintain the level of financing), but the tasks that will be realized by the common agricultural policy. The authors are of the opinion that the added value in agriculture should not be examined exclusively in the financial dimension since it has its source in the realization of the major objective - creating such conditions in which agriculture will be multifunctional, market sustainable, and will be able to keep up rural areas, i.e. to protect nature and make a considerable contribution to the vitality of the rural life. Under the market conditions, farmers are under great pressure to increase productivity, the scale of specialization production, which makes it harder to fulfill its extra commercial function. At the same time, the market, driven by the principle of leveling marginal costs, supports the concentration of the agricultural production in regions adapt to it, and the production decline in the areas far less advantageous environmental and economic conditions. Due to this fact, the declarations regarding sustainability and creating a European agricultural model often do not correspond to the real processes (Zegar, 2010b). Thereby, a hypothesis has been formulated that the implementation of the common agriculture policy principles corrects unreliability of the market mechanism (a part of the economic surplus which under market conditions "leaks" to the nonagricultural sectors, comes back to agriculture, mainly through the tax system) and it is legitimate not only from the point of view of the economic efficiency, but also for social and environmental reasons.

The leitmotif of the changes in CAP after 2013 is to level the direct payments in the EU scale. The legislative proposals of the European Commission, agreed on with the member states, assume, however, that it will not be a "flat rate" system ${ }^{10}$, but that in the countries that receive direct payments per ha below $90 \%$ of the average for the EU, the payment will be increased by a third of the difference between the balance as for 2013 and $90 \%$ of the EU average (from 2013), while maintaining the phasing-in principle. The resources needed for this redistribution will come from the countries that receive payments above the EU average, proportionally to the level of these subsidies. Although Poland will benefit from such reform, the benefit will be insignificant, running at 6-8 euro/ha (Czyżewski and Stępień, 2012).

The evaluation of the above solution from the point of view of the Polish agriculture is ambiguous - first of all, because the changes are distant from the solution proposed by Poland to make the subsidies rates uniform, and second of all, because they strengthen a payment system based on historical crops which is unfair for many countries. Although theoretically the SPS (single payment scheme) system is eliminated, and the direct payments are entirely separated from production (with some exceptions), the level of the future national ceilings will still be based on the current amounts which in turn are the result of the past negotiations taking into account the

\footnotetext{
${ }^{10}$ A single EU-wide payment rate per hectare calculated by dividing the pool of direct payments by the number of UAA in the EU.
} 
reference crop system. If we recognize the failure of the reference crop and base areas established during the Copenhagen negotiations, which constituted the base to calculate the payment envelope for Poland, the new programming period changes really little in this scope. In relation to 2013, when Poland reaches the full level of subsidies, it will be an increase of merely $1.7 \%$ in an annual perspective (in current prices). Although, if we take into account the whole amount of payments granted for the years 2014-2020, in comparison with the current budget the amount will increase by as much as $42 \%^{11}$. The increase, at least partially, will compensate to Poland the annual average draining of rents from agriculture in the long-term perspective, as well as it will reduce the asymmetry in their division (in various phases of the business cycle).

The second important reason for the changes in the direct payments system is the obligation to allot at least $30 \%$ of the national payment envelope to the "green component". It implies the necessity to diversify crops (minimum 3 crops in a farm), maintenance of the current surface area of the permanent grassland, with the right to reduce the acreage by not more than 5\% compared with the reference year, and allocation of a part of the arable land for ecological purposes (Czubak et al., 2011). This is the most arguable point of the EC's proposal because of its microeconomic results, the influence on the sustainable development, and a long-term strategy for the EU agriculture.

The third important assumption of the changes in CAP is the "flexibility" of the direct payment envelope. The flexibility consists in possibilities of multidirectional use of the $1^{\text {st }}$ pillar envelope as well as transferring a part of the resources from the $2^{\text {nd }}$ pillar, according to the following scheme:

- up to $10 \%$ of the direct payment envelope may be transferred to the so-called production-linked support (that is, e.g., the support for specific agricultural sectors of a given country),

- up to $5 \%$ of agriculture for the support for areas with natural constraints (these are not less favoured areas),

- up to $2 \%$ for payments for "young farmers"

- for countries where the level of payments is lower than $90 \%$ of the community average (including Poland), the possibility to transfer up to $5 \%$ of the $2^{\text {nd }}$ pillar resources for direct payments.

A big advantage of transferring resources is the possibility to redirect the $1^{\text {st }}$ pillar to the intensive development (so-called differential rents) and sustainable development (the authors call it an institutional rent). The current evaluations of the absorption of the $1^{\text {st }}$ pillar resources vary, although many claim they have a negative influence on the productivity of the production factors. Therefore, let's assume that it is not the best instrument for improving competitiveness and reaching differential advantages. Thus, it should be aimed, in particular, at those farms whose development is not determined by larger capital intensification and is more extensive. On the other hand, the entities whose rents are "differentially" conditioned should have an easier access to the investment support. For this purpose the above mentioned transfer of $10 \%$ of the direct payment envelope could be allotted.

Taking into account the fact that pro-equality (direct payments) and pro-ecological support dominates in amounts, as many transfers as possible should be made to increase potential resources for modernization. In practice, it implies the necessity to allot most of the $2^{\text {nd }}$ pillar resources to that purpose and to reallocate as many resources from the $1^{\text {st }}$ pillar as possible. What we mean by that is the use of the above mentioned $10 \%$ and $2 \%$ of potential transfers within the $1^{\text {st }}$ pillar, a complete resignation from the $5 \%$ transfer between the $2^{\text {nd }}$ and the $1^{\text {st }}$ pillars, resignation from $5 \%$ of resources for supporting the areas with natural limitations ${ }^{12}$, and maximum limitation of the flat rate

\footnotetext{
${ }^{11}$ In 2007-2013, direct payments envelope was a total of 15222 million $€$, and in the 2013 (after obtaining $100 \%$ of the annual envelope) will be 3045 million $€$. In the new programming period 21689 million $€$ is provided for Poland, ie. an average of 3098 million per year. See: (Plewa, 2011)

${ }^{12}$ In accordance with the principle that it is more efficient to recycle these resources for area payments.
} 
for small agricultural producers ${ }^{13}$. It is worth remembering that in the $2^{\text {nd }}$ pillar's structure, there again will be some constant pro-equality elements - the liabilities on account of structural rents and the less favourable areas (LFA). According to Rowiński, when RDP 2007-2013 was being prepared, more than $35 \%$ of resources had already been allocated, including over $17 \%$ for settling the liabilities for the years 2004-2006, and close to $19 \%$ for covering actions which could not have been cancelled due to so-called acquired rights. It is the question of structural rents and subsidizing mountain areas and other LFA management (Rowiński, 2008). A similar situation may appear during the new programming period. That is why, according to the authors, the priority of allocating the remaining resources from RDP 2014-2020 should be modernization and supporting farm production investments in Poland, secondly taking into consideration the programs stimulating the horizontal integration in agriculture, but not more than at the level of the actual use of these resources in RDP 2007-2013. Table 1 shows the optimum allocation of resources from the point of view of sources of land rent.

The fourth reason for the CAP changes is an introduction of capping. This principle assumes that the amount of direct payments to which a farmer in entitled in the calendar year should be subject to reduction according to the following rules (Majewski, 2011):

- $20 \%$ for payment over $150,000 €$ and lower than 200,000€;

- $40 \%$ for payment over 200,000€ and lower than 250,000€;

- $70 \%$ for payment over $250000 €$ and lower than 300,000€;

- $100 \%$ for payment over 300,000€.

In Poland the capping principle will, if necessary, concern farms of around 700 ha. In 2010 in Poland, only 802 entities out of 1.362 million beneficiaries received direct subsidies exceeding 150,000 euro. These farms used 980,000 ha, which was 7\% of the total area included in the payment program, and the support payments received by these entities amounted to approximately 980,000 million PLN (about 7,8\%) (Czubak et al., 2011). In the authors' opinion, "capping" is the legislator's unvoiced aspiration to use the land rent criterion in allocating direct payments. This principle should concern those farms that realize higher land rent than the farm land prices in the given area would suggest (it is the question of the above mentioned "institutional surplus"). It has not been determined yet, if the farms over 700 ha meet this criterion due to confirmed occurrence of other than differential land rents determinants.

The last, fifth reason for the CAP changes is the lump sum for small farms, which is mainly to simplify the system and lower its transaction costs. The EC proposal assumes that it will be possible to allot to this purpose up to $10 \%$ of the national direct payments envelope for farms whose amount of support does not exceed $15 \%$ of the average support in a member state or the amount equal to the average national payment per hectare multiplied by maximum three (Czubak et al., 2011). In the authors view, however, the benefits of simplifying the system in this matter should be balanced with the losses resulting from strengthening of the fragmented agricultural structure and "blocking" the process of land concentration. The lump sum payment should be high enough to be an alternative to applying for single payments which requires meeting specific conditions of agriculture and many formal efforts. However, it should also be low enough so that small farms would not refrain from sales or land lease. Therefore, the proposal of twice the area payments rate from 2013 seems reasonable. An opportunity arises here for 2- and 3-ha farms, which by using the lump sum payment may lease 1-2 ha to bigger farms for "greening" purposes. This way the land that often does not provide the owner with any land rent because it is not productive enough or maintained in good culture, has a chance to receive such a rent.

\footnotetext{
${ }^{13}$ In the sense that support small farms does not enhance agrarian transformation.
} 
The potential allocation of CAP funds in Poland divided into pro-efficience and pro-equlity measures.

\begin{tabular}{|c|c|c|}
\hline Specification & $\begin{array}{l}\text { Amount in I Pillar in } \\
\text { the period 2014-2020 }\end{array}$ & $\begin{array}{c}\text { Amount in II Pillar in the } \\
\text { period 2014-2020 }\end{array}$ \\
\hline \multicolumn{3}{|c|}{ Pro-efficience measures } \\
\hline $5 \%$ of Pillar I - specific sectors & $1084450000 €$ & \\
\hline $2 \%$ of Pillar I - young farmer & $433780000 €$ & \\
\hline $\begin{array}{l}65 \% \text { of Pillar II - farms modernization, adjustment of } \\
\text { small farms, other pro-investment programs }\end{array}$ & & $8604678500 €$ \\
\hline SUM & \multicolumn{2}{|c|}{$10122908500 €(29 \%$ of all funds in CAP $)$} \\
\hline \multicolumn{3}{|c|}{ Pro-equality measures } \\
\hline $6 \%$ of Pillar I - a lump sum for small farms (max 3ha) & $1314801600 €^{1}$ & \\
\hline $\begin{array}{l}87 \% \text { of Pillar I - area payments } \\
\text { (including } 30 \% \text { of ,greening” component) }\end{array}$ & $\begin{array}{r}18855968400 € \\
(\text { ca. } 205 € / \text { ha per year) })^{2}\end{array}$ & \\
\hline $20 \%$ of Pillar II - structural rents & & $2651584000 €^{3}$ \\
\hline $14 \%$ of Pillar II - LFA (less favourable areas) support & & $1885537500 €^{4}$ \\
\hline $0,06 \%$ of Pillar II - farm groups & & $88200000 €^{5}$ \\
\hline SUM & \multicolumn{2}{|c|}{$24796091500 €(71 \%$ of all funds in CAP $)$} \\
\hline
\end{tabular}

430800 farms of 1 to 3 ha multiplied by 436 euro, i.e. a lumpsump which a farm of 2 hectares will receive in 2013 r, and by 7 years. In authors' opinion if a lumpsum is attributed to the farms of 1 to 3 ha, its amount should be balanced on a level of payment acquired by 2 hectares farm in 2013.

2. (18 $855968400 / 7)$ :( 13980489 ha entitled to payments - 850000 ha of farms receiving a lumpsum)

${ }^{3}$ Basing on forecasted limit for 2014 according to programming period 2017-2013.

${ }^{4}$ Basing on forecasted limit for 2014 according to programming period 2017-2013.

${ }^{5}$ Basing on forecasted limit for 2014 according to programming period 2017-2013.

Source: Own performance on the basis of Ocena Średniookresowa Programu Rozwoju Obszarów Wiejskich na lata 2007-2013. 2011. Finish report of the Euroepan Commission, Vol. I, 109; online: http://ec.europa.eu/agriculture/rurdev/countries/pl/mte-rep-pl_pl.pdf [access data: 10.1.2012].

A basic assumptions of the CAP reform presented above show the different directions of changes in the system of direct payments. Some of them are positively evaluated in the context of the interests of Polish agriculture, others have a negative effect. The new mechanism of direct payments proposed by the European Commission (2011) or individual EU countries is the result of long-term negotiations. The information provided in the table 2 shows high differences in opinions of the EU countries, but also indicate areas in which compromise is close. It follows that the question of the future of CAP is a complex issue, and in many points debatable. To reach compromise, it will be necessary to make concessions from all Member States.

\section{Conclusions}

On the basis of the evaluation of the new direct payments system and their implications for agriculture in Poland, it is possible to state that the EC's proposal is a consequence of graduality of the agricultural system under conditions of economic growth, economic integration, and societies growing wealthy. This graduality is probably a universal development feature of agriculture, although the aim of this paper was not to empirically prove such thesis. In the European agricultural model there clearly appeared two development stages and currently the third one is being developed. The first stage lasted until the beginning of the 1950's and was a period subordinated to the food self-sufficiency priority (Adamowicz, 2005). The second fundamental stage of the agricultural policy was clearly prototypical. Its realization began in 1992 together with the introduction of Mac Sharry's reform and implementation of compensating payments for farmers. It allowed a gradual reduction of institutional prices and creation of an increased demand for the Community's agricultural products, and at the same time it allowed undesirable supply increase (Małysz, 2001). The next CAP changes introduced after 1992 were a continuation of the stipulation 
of Mac Sharry's reform and underlined more and more the idea of interdependence of subsidies and sustainable development criteria ("cross-compliance").

Table no.2.

Evaluation of a new system of direct payments in selected EU countries

\begin{tabular}{|l|l|l|}
\hline $\begin{array}{l}\text { The proposed changes to the direct } \\
\text { payment system }\end{array}$ & $\begin{array}{l}\text { Positive evaluation of changes in } \\
\text { selected countries: }\end{array}$ & $\begin{array}{l}\text { Negative evaluation of changes } \\
\text { in selected countries: }\end{array}$ \\
\hline $\begin{array}{l}\text { Direct payments as a main instrument of } \\
\text { the CAP }\end{array}$ & $\begin{array}{l}\text { Most Member States, including } \\
\text { Poland }\end{array}$ & Great Britain, Sweden \\
\hline $\begin{array}{l}\text { Maintaining the diversity of the rates of } \\
\text { direct payments }\end{array}$ & $\begin{array}{l}\text { Germany, France, Netherlands, } \\
\text { Belgium, Denmark }\end{array}$ & $\begin{array}{l}\text { Poland, Lithuania, Latvia, } \\
\text { Romania, Slovakia, Estonia, Spain, } \\
\text { Portugal }\end{array}$ \\
\hline $\begin{array}{l}\text { Purchasing power as the criterion for the } \\
\text { calculation of rate of direct payments }\end{array}$ & $\begin{array}{l}\text { Germany, France, Netherlands, } \\
\text { Denmark }\end{array}$ & $\begin{array}{l}\text { Poland, Lithuania, Latvia, } \\
\text { Estonia, Romania, Bulgaria }\end{array}$ \\
\hline $\begin{array}{l}\text { Reduction of direct payments to the } \\
\text { largest farms (capping) }\end{array}$ & $\begin{array}{l}\text { Poland, Romania, Lithuania, } \\
\text { Latvia, Italy, Portugal }\end{array}$ & $\begin{array}{l}\text { Czech Republic, France, Denmark, } \\
\text { Germany, Netherlands, Austria, } \\
\text { Sweden, Finland }\end{array}$ \\
\hline "Greening" of the direct payments & $\begin{array}{l}\text { Sweden, Great Britain, Germany, } \\
\text { France, Netherlands, Denmark }\end{array}$ & $\begin{array}{l}\text { Poland, Romania, Lithuania, } \\
\text { Latvia, Spain, Slovakia }\end{array}$ \\
\hline $\begin{array}{l}\text { Lump sum payments for small farmers } \\
\text { Most Member States, mainly } \\
\text { Poland, Romania, Italy, Greece, } \\
\text { Bulgaria }\end{array}$ & \begin{tabular}{l} 
No clear negative ratings \\
\hline $\begin{array}{l}\text { The possibility of transferring funds from } \\
\text { the II (rural development) to the I pillar } \\
\text { (direct payments) }\end{array}$
\end{tabular} $\begin{array}{l}\text { Most Member States, including } \\
\text { Poland }\end{array}$ & $\begin{array}{l}\text { Great Britain, Sweden, } \\
\text { Netherlands }\end{array}$ \\
\hline
\end{tabular}

Source: Own performance on the basis of Proposal for a regulation of the European Parliament and of the Council..., 2011; Mottershead, 2011; Allain, 2011; Lapis A., 2011; Lapperre R., 2011; Manana N., 2011.

The current EC proposal from 2011 concerning CAP in the programming period 2014-2020 is expansion of this idea. This stage is distinguished by changes in the model of agricultural sector product consumption and takes into account the usefulnesses linked to the well-being of the natural environment. A special significance is attributed to the farmers providing public goods, for which, though, they do not get remunerated by the market. Therefore, there occurs a premise, also of economic rationality character, that justifies the idea of remunerating agricultural producers from public funds. All the more so because, as underlined by W. Poczta, the farmers need to meet high requirements in the scope of food safety, fulfilling environmental protection standards, people and animals health protection, and care for the well-being of animals. Without the support of public funds, meeting these criteria would be impossible and there would occur harmful social processes of concentration of the manufacturing potential. In practice, it implies setting up enormous plant monocultures in the areas of best natural conditions and concentration of animal production on a large scale in big farms (Poczta, 2010). It contradicts the idea of environmental, spatial, social and economic order, and therefore the whole sustainable development concept.

It should be noticed that considering agriculture and rural communities as public goods suppliers implies a conclusion that not only the areas of agricultural land in particular countries but also the number of people employed in the agricultural sector (!) should be the division criteria of direct payments envelopes in the EU. Unfortunately, the EC proposal concerning the future programming period does not take into account the second part of the above observation because the direct payments per person employed in the agricultural sector are characterized by gross disproportion between the 15 countries of the "old" EU and the new members. Moreover this disproportion will maintain. It is a clear inconsistency which results from the contradiction between particular national interests and the strategic goals of the entire EU. Such contradictions cannot be avoided. Paradoxically, though, their occurrences do not need to mean a decision-making chaos and 
does not entitle to propose a thesis about the lack of a long-term strategy for the agricultural development in the EU (Grochowska and Rowiński, 2011). It would be a classic assumption error. The sum of the microeconomic inefficiencies does not have to indicate inefficiency in the macro scale. It is obvious that the EU countries differ in the microeconomic effectiveness of allocating labour resources and capital in agriculture, and that because of it they should undertake different actions in this scope. It is possible due to the elasticity in allocating subsidies in the $1^{\text {st }}$ and $2^{\text {nd }}$ pillars of CAP, which Poland should use, taking into consideration its particular national interests. In the authors' opinion, the maximally pro-efficiency and modernization orientation of the $1^{\text {st }}$ and $2^{\text {nd }}$ pillars of CAP within a binding institutional framework is in the interest of the Polish agriculture. It does not, however, thwart the common long-term EU strategy oriented to sustainable development.

\section{Acknowledgements}

Article written by the project funded by the National Science Centre in Poland allocated on the basis of Decision No DEC-2011/01/D/HS4/01842 from 13.10.2011 and the project funded by the National Science Centre in Poland, on $40^{\text {th }}$ contest of the research projects, No N N112 38354

\section{References}

1. Adamowicz M., 2005. Przesłanki rozwoju wielofunkcyjności rolnictwa i zmian we Wspólnej Polityce Rolnej, Zagadnienia Ekonomiki Rolnej, vol. 1, pp. 22-27

2. Allain E., 2011. Greening of the CAP: the French Visio (presentation), Ministry of Agriculture, Food, Fisheries, Rural Affairs and Spatial Planning, Paris

3. Czubak W., Poczta W., Sadowski A., 2011. Wptyw proponowanej reformy systemu dopłat bezpośrednich po 2013 roku na sytuację polskiego rolnictwa, Wieś i Rolnictwo, vol. 4, pp. 61-65

4. Czyżewski A., 2010. Co dała integracja europejska polskiej wsi - w opinii ekonomisty, In. Wilkin J, Nurzyńska I. (Eds), 2010. Polska wieś 2010. Raport o stanie wsi, Warsaw, Foundation for the Development of Polish Agriculture, pp. 164-166

5. Czyżewski A., Stępień S., 2012. Dostosowania mechanizmów WPR do oczekiwań państw członkowskich, Ekonomista, vol. 2

6. Czyżewski B., 2010. Controversies Concerning the Rent of Land From Classical Economics to Modern Times, Ekonomista, vol. 2.

7. Czyżewski B., 2012. Economic Rents in Agribussines in Poland, PWE, Warszawa

8. Finish report of the Euroepan Commission, Vol. 2011. European Commission, Brussels

9. Grochowska R., Rowiński J., 2011. Wsparcie rolnictwa w wybranych krajach, Presentation on the conference „Competitiveness of the food industry in the context of globalization and European integration", Puttusk, 5-7 December

10. Lapins A., 2011. Direct payments - distrinition criteria. Latvian contribution (presentation), Conference „Direct payments under the CAP 2020”, Warsaw, 16th June

11. Lapperre R., 2011. Greening of the CAP, enhancing sustainability and innovation (presentation), The Netherlands Ministry of Economic Affairs, Agriculture and Innovation, Hague

12. Majewski E., 2011. Koncepcja oszacowania skutków reform Wspólnej Polityki Rolnej UE w perspektywie budzetowej 2014-2020, Warsaw, Institute of Agricultural and Food Economics - National Research Institute

13. Manana N., 2011. Direct payments in the CAP 2020: Distribution criteria, Ministry of Agriculture - Office for Planning and Policies, Lisbon

14. Małysz J., 2001. Reorientacja WPR - implikacje dla krajów kandydackich, Wieś i Rolnictwo, vol. 1 
15. Mottershead D., 2011. Allocation of Direct Payments, Department for Environment, Food and Rural Affairs, London.

16. Ocena Średniookresowa Programu Rozwoju Obszarów Wiejskich na lata 2007-2013 (za okres 2007-2009). 2010. Expertise by Agrotec Polska Sp. z o.o., Institute of Agricultural and Food Economics and The Institute of Soil Science and Plant Cultivation on request of the Ministry of Agriculture and Rural Development, Warsaw, 28-29.

17. Plewa J., 2011. WPR do 2020r. Propozycje ustawodawcze Komisji (presentation), Brussels, European Commission - DG Agri

18. Poczta W., 2010. Wspólna polityka rolna UE po 2013 roku-uzasadnienie, funkcje, kierunki rozwoju w kontekście interesu polskiego rolnictwa, Wieś i Rolnictwo, vol. 3

19. Proposal for a regulation of the European Parliament and of the Council establishing rules for direct payments to farmers under support schemes within the framework of the common agricultural policy. COM (2011) 625 final/2. 2011. European Commission, Brussels 2011.

20. Rowiński J., 2008. Program Rozwoju Obszarów Wiejskich na lata 2007-2013 (Analiza zatwierdzonej wersji programui pierwszych lat realizacji) - Program Wieloletni 2005-2009, Report no 118. Warsaw, Institute of Agricultural and Food Economics - National Research Institute, 127-131

21. Statistical Yearbook of Agriculture. 2011. Warsaw, Central Statistical Office.

22. The CAP Reform - an explanation of the main elements (MEMO/11/685), 2011. European Commission, Brussels

23. Zaleski J., Tomaszewski P., Zembaty M., 2007. Ocena wpływu Programu Rozwoju Obszarów Wiejskich (PROW) na lata 2007-2013 na polska gospodarkę przy użyciu modelu makroekonomicznego HERMIN (expertise), Wroclaw, Regional Development Agency, 1335

24. Zegar J.S., 2010a. Ekonomia wobec kwestii agrarnej, Ekonomista, vol. 6

25. Zegar J.S., 2010b. Wspólna Polityka Rolna po 2013 roku, Wieś i Rolnictwo, vol. 3 